DOI: http://dx.doi.org/10.18203/2319-2003.ijbcp20203629

\title{
The impact of vitamin D3 supplementation on glycemic control in type- 2 diabetes mellitus at a tertiary care hospital
}

\author{
Neeta Banzal, Anupama Desai*
}

Department of Pharmacology, Surat Municipal Institute of Medical Education and Research, Surat, Gujarat, India

Received: 26 July 2020

Revised: 18 August 2020

Accepted: 19 August 2020

\section{*Correspondence:}

Dr. Anupama Desai,

Email: akj01936@yahoo.com

Copyright: (C) the author(s), publisher and licensee Medip Academy. This is an open-access article distributed under the terms of the Creative Commons Attribution Non-Commercial License, which permits unrestricted non-commercial use, distribution, and reproduction in any medium, provided the original work is properly cited.

\begin{abstract}
Background: It has been estimated that at least one billion people worldwide have vitamin D3 deficiency. Type 2 diabetes mellitus has consistently been shown to be prevalent in individuals with vitamin D3 deficiency. This study focuses on exploring if there is any association between vitamin D3 deficiency, type 2 diabetes mellitus and glycemic control, by measuring HbA1c levels, after vitamin D3 supplementation.

Methods: 77 patients with confirmed type II diabetes mellitus were enrolled during the study. Pre and post treatment (after 3 month) laboratory investigations - FBS, PPBS, HbA1c and serum vitamin D3 levels were done in all the patients. Patients were classified into two groups. Group 1 - vitamin D3 $<30 \mathrm{ng} / \mathrm{ml}(\mathrm{n}=41)$ and group 2 - vitamin D3 $\geq 30 \mathrm{ng} / \mathrm{ml}(\mathrm{n}=36)$. Group 1 was given $60,000 \mathrm{IU}$ of calcitriol sachet weekly for 8 weeks followed by $60,000 \mathrm{IU}$ once a month. No vitamin D3 supplementation was given to group 2.

Results: Vitamin D3 supplementation in group 1, has resulted in number of patients with control on $\mathrm{HbA1c}(<7 \%)$ increased from 8 to 17 (a more than 100\% increase). Number of patients with control on FBS ( $<130 \mathrm{mg} / \mathrm{dl})$ increased from 14 to 23 (64\% increase).

Conclusions: There is a positive association between vitamin D3 status and glycemic control in type 2 diabetic mellitus patients. Vitamin D3 supplementation in deficient group has resulted in significant reduction in HbA1c level $(\mathrm{p}<0.001)$.
\end{abstract}

Keywords: Vitamin D deficiency, Type 2 diabetes, Glycemic control, HbA1c, FBS, PPBS

\section{INTRODUCTION}

Vitamin $\mathrm{D}_{3}$ deficiency and diabetes mellitus are two common conditions that are widely prevalent across people of all ages, races, geographical regions, and socioeconomic classes. A lot of current focus is on the role of vitamin $\mathrm{D}_{3}$ deficiency in the pathogenesis and development of type 2 diabetes. Inadequate exposure to sunlight and inadequate dietary intake of vitamin $\mathrm{D}_{3}$ are leading to a widespread deficiency in all ages. ${ }^{1}$

Vitamin $\mathrm{D}_{3}$ plays an important part in the regulation of calcium. Calcium besides having multiple functions in our body systems also helps to facilitate the release of insulin, so a decrease in calcium has a negative effect on beta cell function, which may affect normal insulin release. Type 2 diabetes mellitus has consistently been shown to be prevalent in individuals with vitamin $\mathrm{D}_{3}$ deficiency. The condition is characterized by insulin resistance and altered insulin secretion, associated with defects in pancreatic beta cell function.

It has been reported through various animal and human studies that vitamin $\mathrm{D}$ has a role in controlling glucose metabolism besides having a role in skeletal functions. There has been increasing evidence to suggest that vitamin $\mathrm{D}$ may be important in modifying risk of type 2 diabetes. Vitamin D is supposed to have an effect on both 
direct (through activation of the vitamin $\mathrm{D}$ receptor) and indirect (via regulation of calcium homeostasis) mechanisms related to the pathophysiology of type 2 diabetes. The effect of vitamin $\mathrm{D}$ is also seen on pancreatic beta-cell dysfunction, impaired insulin action, and systemic inflammation. The evidence comes from cross-sectional and a few prospective observational human studies showing an inverse association between vitamin $\mathrm{D}$ status and prevalence or incidence of type 2 diabetes. $^{2}$ Vitamin $\mathrm{D}_{3}$ replenishment may improve glycemic control and insulin secretion in patients with type 2 diabetes mellitus with established hypovitaminosis $\mathrm{D}_{3}$, thereby suggesting a role for vitamin $\mathrm{D}_{3}$ in pathogenesis of diabetes mellitus. ${ }^{3}$

There has been a lack of conclusive evidence to establish the role of vitamin $\mathrm{D}_{3}$ in prevention or treatment of type 2 diabetes.

The objective of this study was to explore if there is any association between vitamin $\mathrm{D}_{3}$ deficiency, type 2 diabetes mellitus and glycemic control, by measuring HbA1c levels after vitamin $\mathrm{D}_{3}$ supplementation.

\section{METHODS}

This was an observational study carried out at departments of pharmacology and medicine at a tertiary care hospital Surat Municipal Institute of Medical Education and Research (SMIMER), Surat. In this study, patients attending medicine OPD and diagnosed with confirmed type II diabetes mellitus for more than six months were included. The permission of the ethics committee of the institute was taken prior to the commencement of the study.

\section{Sample size calculation}

Sample size (n) was calculated by using the following formula,

$$
\mathrm{n}=\frac{(\mathrm{Z} \alpha / 2) \times(\mathrm{Z} \alpha / 2) \times \mathrm{p} \times q}{\mathrm{LX} \mathrm{L}}
$$

Where $\mathrm{p}$ is the proportion of diabetic patients attending medicine OPD. It was obtained by one-month pilot survey and was found to be $7.5 \%$. $\mathrm{q}$ is the proportion of non-diabetic population attending the medicine OPD, which is 1 -p i.e. $92.5 \%$. $Z \alpha_{/ 2}$ is standard normal variate, at the level of significance $95 \%(\mathrm{p}<0.05)=1.96$.

$\mathrm{L}$ is the allowable error taken as $6 \%$. The value of $\mathrm{n}$ by putting the respective values comes out to be 74 .

$$
n=\frac{1.96 \times 1.96 \times 0.075 \times 0.925}{0.06 \times 0.06}
$$

\section{Grouping of patients}

According to level of vitamin $\mathrm{D}_{3}, 77$ patients were classified as two groups.

Group 1: 41 patients with vitamin $\mathrm{D}_{3}<30 \mathrm{ng} / \mathrm{ml}$ referred as vitamin $\mathrm{D}_{3}$ deficient group or simply $\mathrm{Gp} 1$.

Group 2: 36 patients with vitamin $\mathrm{D}_{3}>30 \mathrm{ng} / \mathrm{ml}$ referred as vitamin $\mathrm{D}_{3}$ sufficient group or Gp2.

Accordingly, 77 patients with confirmed type II diabetes mellitus meeting the above criteria were eventually taken for study. Informed written consent was taken from the patients for using their clinical data for the study purpose. Laboratory investigations like FBS, PPBS, HbA1c and serum vitamin $D_{3}$ were carried out in all the patients. Serum vitamin $\mathrm{D}_{3}$ was measured by the method of electrochemiluminescence immunoassay (ELCIA). These parameters were recorded and noted as "pre-treatment" levels.

Gp1 patients were given 60,000 IU of calcitriol sachet weekly for 8 weeks followed by 60,000 IU once a month, along with prescribed medication by physician. Patients were telephonically reminded for compliance and follow up. Gp2 patients were asked to continue treatment of physician only. No vitamin $\mathrm{D}_{3}$ supplementation was given to this group.

All the patients were given dietary and life style modification advice. Patients were asked regarding general wellbeing or any problems during the study period. After a gap of 3 months, repeat investigation for FBS, $\mathrm{PP}_{2} \mathrm{BS}, \mathrm{HbA} 1 \mathrm{c}$ and serum vitamin $\mathrm{D}_{3}$ were carried out in all the patients (GP1 and Gp2) to get the data for analysis. These levels were recorded and noted as "post treatment" levels. OPD patients of age more than 18 years attending the department of medicine having history of diabetes mellitus type II for more than 6 months were included. Patients having history of liver disease, chronic heart disease or any other chronic illness, patients with nephropathy or renal failure, pregnant woman and patients of history of calcium supplementation or history of vitamin $\mathrm{D}_{3}$ supplementation in last three months were excluded from the study.

\section{Statistical analysis}

The data was analysed by descriptive statistics such as mean, SD (standard deviation), bar graphs, paired t-test, independent t-test were applied to know the effectiveness of pre and post comparison of variables. Statistical analysis was done by SPSS20.

\section{Ethical approval}

The permission of the ethics committee of the institute was taken prior to the commencement of the study. 


\section{RESULTS}

Pre-treatment values refer to values of parameters (vitamin $\mathrm{D}_{3}, \mathrm{HbA} 1 \mathrm{c}, \mathrm{FBS}, \mathrm{PPBS}$ ) recorded in all subjects (Gp1 and Gp2) at the beginning of the study.

Post-treatment values refer to values of parameters (vitamin $\mathrm{D}_{3}, \mathrm{HbA} 1 \mathrm{c}, \mathrm{FBS}, \mathrm{PPBS}$ ) recorded after vitamin $\mathrm{D}_{3}$ supplementation in $\mathrm{Gp} 1$ patients and without vitamin $\mathrm{D}_{3}$ supplementation in $\mathrm{Gp} 2$ patients after three months of follow up.

The study population constituted of predominantly male patients. There were $55(71 \%)$ males and 22 females in the study population. The proportion of female was $41.5 \%$ in vitamin D3 deficient group as compared to vitamin D3 sufficient group in which it was $13.9 \%$. There were more patients $74 \%$ in the age group of more than or equal to 50 years in the study population.

Table 1: Demographic data.

\begin{tabular}{|c|c|c|}
\hline Parameters & $\begin{array}{l}\text { Gp1 (n=41) } \\
\mathbf{N}(\%)\end{array}$ & $\begin{array}{l}\text { Gp2 }(\mathbf{n}=36) \\
\mathbf{N}(\%)\end{array}$ \\
\hline \multirow{2}{*}{ Gender } & M:24 (58.5) & M:31 (86.1) \\
\hline & $\mathrm{F}: 17$ (41.5) & F:5 (13.9) \\
\hline \multirow{2}{*}{ Age } & $\begin{array}{l}<50 \text { years: } 14 \\
(34.1)\end{array}$ & $\begin{array}{l}<50 \text { years:06 } \\
(16.7)\end{array}$ \\
\hline & $\begin{array}{l}\geq 50 \text { years: } 27 \\
(65.9)\end{array}$ & $\begin{array}{l}\geq 50 \text { years: } 30 \\
(83.3)\end{array}$ \\
\hline \multirow{2}{*}{$\begin{array}{l}\text { Socio- } \\
\text { economic } \\
\text { status }\end{array}$} & $\begin{array}{l}<4.2 \mathrm{~L} / \text { year:36 } \\
(87.8)\end{array}$ & $\begin{array}{l}\text { <4.2 L/year:29 } \\
(80.6)\end{array}$ \\
\hline & $\begin{array}{l}>4.2 \mathrm{~L} / \text { year:05 } \\
(12.2)\end{array}$ & $\begin{array}{l}>4.2 \text { L/year:07 } \\
(19.4)\end{array}$ \\
\hline \multirow{2}{*}{$\begin{array}{l}\text { Duration of } \\
\text { diabetes }\end{array}$} & $\begin{array}{l}2 \text { to } 10 \text { years: } 31 \\
(75.6)\end{array}$ & $\begin{array}{l}2 \text { to } 10 \text { years: } 26 \\
(72.2)\end{array}$ \\
\hline & $\begin{array}{l}>10 \text { years: } 10 \\
(24.4)\end{array}$ & $\begin{array}{l}>10 \text { years: } 10 \\
(27.8)\end{array}$ \\
\hline \multirow{2}{*}{$\begin{array}{l}\text { Dietary } \\
\text { habits }\end{array}$} & $\begin{array}{l}\text { Vegetarian: } 27 \\
(65.9)\end{array}$ & $\begin{array}{l}\text { Vegetarian:20 } \\
(55.6)\end{array}$ \\
\hline & $\begin{array}{l}\text { Non veg:14 } \\
(34.1)\end{array}$ & $\begin{array}{l}\text { Non-veg: } 16 \\
(44.4)\end{array}$ \\
\hline
\end{tabular}

\section{Drug utilization pattern in study population}

Most of the patients $94.8 \%$ were on multi-drug therapy. The drug which was used by all the patients was metformin (100\%) followed by glimipiride (94.8\%), voglibose $(27.3 \%)$ and pioglitazone (1.3\%) mainly through combination therapy. The Figure 1, below depicts the drugs utilization pattern in the treatment of type 2 diabetes mellitus.

\section{Pre-treatment lab test data}

Vitamin D3, HbA1c, FBS, PPBS were done for all patients and the data recorded for each group (Table 2).
For HbA1c the division was made considering ADA guidelines which recommend the target level of $\mathrm{HbA1c}$ as $7 \%$ for the management of $\mathrm{HbA} 1 \mathrm{c}$ in most diabetic patients. ${ }^{4}$ In the study, when we consider Gp1 patients, the target level of $\mathrm{HbA} 1 \mathrm{c}<7 \%$ was achieved by $20 \%$ patients and in $\mathrm{Gp} 2,42 \%$ patients had their $\mathrm{HbA} 1 \mathrm{c}<7 \%$.

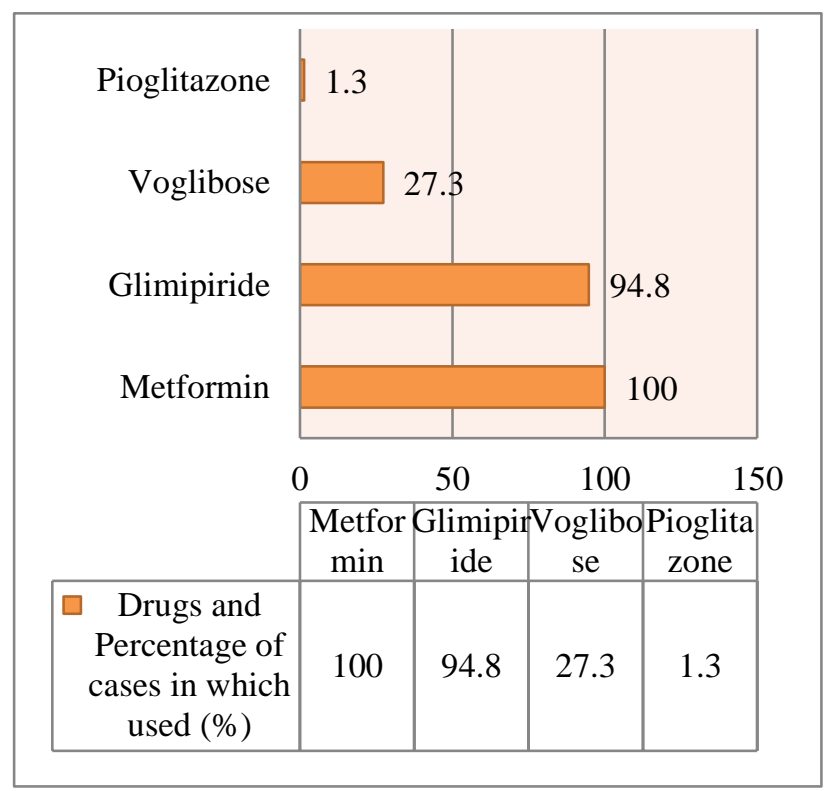

Figure 1: Drug utilization pattern in treatment of diabetes in study population $(n=77)$.

Table 2: Pre-treatment lab reports data.

\begin{tabular}{|llll|}
\hline \multirow{2}{*}{ Test } & Criteria & $\begin{array}{l}\text { Gp1 } \\
(\mathbf{n = 4 1})\end{array}$ & $\begin{array}{l}\text { Gp 2 } \\
(\mathbf{n}=36) \\
\mathbf{N}(\%)\end{array}$ \\
\hline $\begin{array}{l}\text { Vitamin D3 } \\
(\mathbf{n g} / \mathbf{\% l})\end{array}$ & $<30$ & 41 & 36 \\
\cline { 2 - 4 } & $\geq 30$ & $8(20)$ & $15(42)$ \\
\cline { 2 - 4 } HbA1C (\%) & $\geq 7$ & $26(63)$ & $18(50)$ \\
\cline { 2 - 4 } & $\geq 10$ & $7(17)$ & $3(8)$ \\
\hline \multirow{2}{*}{ FBS (mg/dl) } & $\geq 130$ & $14(34)$ & $16(44)$ \\
\cline { 2 - 4 } & $\geq 130$ & $27(66)$ & $20(56)$ \\
\hline \multirow{2}{*}{$\begin{array}{l}\text { PPBS } \\
\text { (mg/dl) }\end{array}$} & $\geq 180$ & $12(29)$ & $19(53)$ \\
\hline
\end{tabular}

As per ADA guidelines FBS target level for diabetes mellitus patients is recommended to be less than 130 $\mathrm{mg} / \mathrm{dl}^{4}$. Further in $\mathrm{Gp} 1,34 \%$ of the population was in target range in comparison to $44 \%$ population in $\mathrm{Gp} 2$. As per American diabetes association guideline, the target range recommended for PPBS levels is less than 180 $\mathrm{mg} / \mathrm{dl} .{ }^{4}$ Accordingly, it is observed that the target level was achieved in $40 \%$ of the patients. If we look within Gp1 and Gp2, it is observed that Gp2 had more population under control with $53 \%$ in comparison to $29 \%$ in Gp1. 
Table 3: Pre-treatment mean vitamin D3, HbA1c, FBS, PPBS level in Gp1 (n=41) and Gp2 (n=36) patients.

\begin{tabular}{|c|c|c|c|c|c|}
\hline Parameters & Gp & Mean & SD & P value & Significance \\
\hline \multirow{2}{*}{ Vitamin D3 (ng/ml) } & Gp1 & 17.3 & 5.9 & \multirow{2}{*}{$<0.001$} & \multirow{2}{*}{ Highly significant } \\
\hline & Gp2 & 40.1 & 8.5 & & \\
\hline \multirow{2}{*}{ HbA1c (\%) } & Gp1 & 8.5 & 2.5 & \multirow{2}{*}{0.063} & \multirow{2}{*}{ Not significant } \\
\hline & Gp2 & 7.6 & 1.5 & & \\
\hline \multirow{2}{*}{ FBS (mg/dl) } & Gp1 & 146 & 39 & \multirow{2}{*}{0.488} & \multirow{2}{*}{ Not significant } \\
\hline & Gp2 & 139.5 & 42.9 & & \\
\hline \multirow{2}{*}{ PPBS (mg/dl) } & Gp1 & 207.4 & 68 & \multirow{2}{*}{0.351} & \multirow{2}{*}{ Not significant } \\
\hline & Gp2 & 192.9 & 67.2 & & \\
\hline
\end{tabular}

Table 4: Pre-treatment and post treatment mean vitamin D3, HbA1c, FBS and PPBS levels in Gp1.

\begin{tabular}{|c|c|c|c|c|c|}
\hline Parameters & Sample size & Mean & SD & P value & Significance \\
\hline \multirow{2}{*}{ Vitamin $D_{3}(\mathrm{ng} / \mathrm{ml})$} & Pre & 17.3 & 5.9 & \multirow{2}{*}{$<0.001$} & \multirow{2}{*}{ Highly significant } \\
\hline & Post & 30.7 & 12.3 & & \\
\hline \multirow{2}{*}{ HbA1c (\%) } & Pre & 8.5 & 2.5 & \multirow{2}{*}{0.005} & \multirow{2}{*}{ Significant } \\
\hline & Post & 7.6 & 1.9 & & \\
\hline \multirow{2}{*}{ FBS (mg/dl) } & Pre & 146 & 39 & \multirow{2}{*}{0.007} & \multirow{2}{*}{ Significant } \\
\hline & Post & 139.5 & 42.9 & & \\
\hline \multirow{2}{*}{ PPBS (mg/dl) } & Pre & 207.4 & 68 & \multirow{2}{*}{0.001} & \multirow{2}{*}{ Highly significant } \\
\hline & Post & 177 & 61.3 & & \\
\hline
\end{tabular}

Table 5: Post treatment mean vitamin D3, HbA1c, FBS and PPBS levels in Gp1 and Gp2 patients.

\begin{tabular}{|c|c|c|c|c|c|}
\hline Parameters & Sample size & Mean & SD & P value & Significance \\
\hline \multirow{2}{*}{ Vitamin $D_{3}(\mathrm{ng} / \mathrm{ml})$} & Gp1 & 30.7 & 12.3 & \multirow{2}{*}{0.0008} & \multirow{2}{*}{ Highly significant } \\
\hline & Gp2 & 39.4 & 7.1 & & \\
\hline \multirow{2}{*}{ HbA1c (\%) } & Gp1 & 7.6 & 1.9 & \multirow{2}{*}{0.264} & \multirow{2}{*}{ Not significant } \\
\hline & Gp2 & 7.1 & 1.3 & & \\
\hline \multirow{2}{*}{ FBS (mg/dl) } & Gp1 & 129.5 & 42.9 & \multirow{2}{*}{0.952} & \multirow{2}{*}{ Not significant } \\
\hline & Gp2 & 128.9 & 30.4 & & \\
\hline \multirow{2}{*}{ PPBS (mg/dl) } & Gp1 & 177.0 & 61.3 & \multirow{2}{*}{0.307} & \multirow{2}{*}{$\begin{array}{l}\text { Not } \\
\text { Significant }\end{array}$} \\
\hline & Gp2 & 164.7 & 40.6 & & \\
\hline
\end{tabular}

\section{Comparative data of pre-treatment levels of vitamin $D_{3}$,} HbA1c, FBS and PPBS between Gp1 and Gp2

It is observed that between the two groups, the difference in vitamin $\mathrm{D}_{3}$ levels were statistically significant. An inverse relationship is observed between the high vitamin $\mathrm{D}_{3}$ level and HbA1c parameters between the two groups. However, the HbA1c levels between the groups were not statistically significant. FBS and PPBS values observed in Gp2 are less than the values observed in Gp1. However, these values are statistically not significant (Table 3).

Comparative data of vitamin $D_{3}, H b A 1 c, F B S$ and PPBS in Gp1 - pre and post supplementation of vitamin $D_{3}$

Gp1 patients were given the vitamin $D_{3}$ supplementation of 60,000 IU for 8 weeks and once a month thereafter and the reading of vitamin $\mathrm{D}_{3}, \mathrm{HbA} 1 \mathrm{C}$, FBS and PPBS were taken after 3 months from the first dose of supplementation. The following are the observations of the parameters before and after the treatment was given to $\mathrm{Gp} 1$. It can be seen that all the parameters had significant change in their values (Table 4).

Comparative data on post treatment levels of vitamin $D_{3}, \mathrm{HbA1c}$, FBS and PPBS between Gp1 and Gp2

The comparison of vitamin $\mathrm{D}_{3}, \mathrm{HbA} 1 \mathrm{c}$, FBS and PPBS mean levels is made between Gp1 and Gp2, after vitamin $\mathrm{D}_{3}$ supplements were given to $\mathrm{Gp} 1$. It was observed that $\mathrm{Gp} 2$ vitamin $\mathrm{D}_{3}$ mean level was higher than the level of Gp1. The independent ' $t$ ' test showed that the difference of vitamin $\mathrm{D}_{3}$ levels was statistically significant.

The HbA1c level between the two groups was not found to be statistically significant. The values in the Gp2 were on the lower side. This also shows the inverse relationship between vitamin $\mathrm{D}_{3}$ level and HbA1c levels (Table 5). 


\section{DISCUSSION}

The mean age in the present study was $55.2 \pm 9.2(n=77)$ years. This is similar to the study carried out by Hamid et al in 2014 in which the mean age was $55 \pm 10.7 \quad(n=60)$ and also similar to the study carried out by Ohk et al in 2014 in which mean age was 54.8 $\pm 7.6(n=64){ }^{5,6}$ The mean age in most of the studies carried out on type 2 diabetic patients is around 55 years. In the age group below 50 years, it is evident that there was a higher prevalence $(34.1 \%)$ of diabetes mellitus in the Gp1 than in the $\mathrm{Gp} 2(16.7 \%)$. This indicates an association of early onset of type 2 diabetes in vitamin $\mathrm{D}_{3}$ deficient subjects. This finding is similar to the finding in the study carried out by Harish et al in 2015 on correlation of vitamin $\mathrm{D}_{3}$ level with glycemic control in type 2 diabetes mellitus $(n=50)$ in which he observed that there were $44 \%$ patients in vitamin $D_{3}$ deficient group $\left(D_{3}<30 \mathrm{ng} / \mathrm{ml}\right)$ in comparison to only $14 \%$ in vitamin $\mathrm{D}_{3}$ sufficient group in the age group below 45 years. $^{7}$

In the present study, the duration of diabetes mean was 6.1 years. This is similar to the mean duration observed in the study carried out by Krul et al in a study as 6 years. ${ }^{8}$ The percentage of patients with a non-vegetarian diet were $39 \%$, comparable to the study of Krul et al $35 \% .{ }^{8}$ It was also noted that the subjects with vegetarian diet were on a higher side $(66 \%)$ in the vitamin $\mathrm{D}_{3}$ deficient group in comparison to the non-vegetarian diet patients (34\%).

It was observed that all patients were on multi drug therapy. All (100\%) have been prescribed metformin and $94.8 \%$, sulfonyl urea group drug glimipride, $\alpha$ glucosidase inhibitor voglibose $(27.3 \%)$, pioglitazone (in $1.3 \%$ ) are given in combination with metformin. This is comparable with the study carried out by Ohk et al on Korean subjects in which $88.6 \%$ were given metformin, followed by $78.5 \%$ sulfonyl urea group, $34.2 \%$ acarbose group and $15.4 \%$ pioglitazone. ${ }^{6}$

In the present study the number of patients having better glycemic control (HbA1c $<7 \%$ as per ADA guidelines) were $20 \%$ in $\mathrm{Gp} 1$ in comparison to $42 \%$ in Gp2, implying an improvement in glycemic control with sufficient vitamin $\mathrm{D}_{3}$ levels. ${ }^{4}$ Similarly, in our study the FBS target level $(<130 \mathrm{mg} / \mathrm{dl}$ as per ADA) was achieved in $34 \%$ patients in $\mathrm{Gp} 1$ in comparison to $44 \%$ in $\mathrm{Gp} 2 .^{4}$

Our study has noted the similar inverse relationship on PPBS and vitamin $\mathrm{D}_{3}$ levels in achieving the target level of $180 \mathrm{mg} / \mathrm{dl}$. Our results match with the findings of Pittas et al in which the author has noted improvement in glycemic control with high level of vitamin $\mathrm{D}_{3} .^{9}$ The finding is also similar to the finding of Brijesh et al in which author noted an inverse correlation through linear regression between vitamin $\mathrm{D}_{3}$ levels and HbA1c levels. ${ }^{10}$ The same is supported by the finding of Harish et al in which he noted a significant inverse relationship with the vitamin $\mathrm{D}_{3}$ level and HbA1c $(\mathrm{p}=0.006){ }^{7}$
In the present study, the vitamin $\mathrm{D}_{3}$ level increased in both the genders significantly $(p<0.001)$. The result of our study matches with the study carried out Ohk et al, Krul et al and Sabherwal et al. ${ }^{6,8,11}$ In the present study $\mathrm{Gp} 1$ patients treated with vitamin $\mathrm{D}_{3}$ supplementation show significant improvement in vitamin $\mathrm{D}_{3}$ level along with significant improvement in the HbA1c $(p=0.005)$, FBS $(p=0.007)$ and PPBS $(p=0.001)$ levels. This suggests a positive relationship between glycemic control and vitamin $\mathrm{D}_{3}$.

The present study also observed that after the vitamin $\mathrm{D}_{3}$ supplementation the number of patients with control on $\mathrm{HbA1c}$ ( $<7 \%$ as per ADA guidelines) increased from 8 to 17 , a more than $100 \%$ increase. ${ }^{4}$ Similarly the number of patients with FBS $<130 \mathrm{mg} / \mathrm{dl}$ considered under control as ADA increased from 14 to 23, an increase of $64 \%$, and number of patients with PPBS $<180 \mathrm{mg} / \mathrm{dl}$ increased from 19 to 27 , an increase of $42 \%$. This shows an improvement in glycemic control with an increase in vitamin $\mathrm{D}_{3}$ levels.

Our study results match with the study carried out by Sabherwal et al who noted that vitamin $\mathrm{D}_{3}$ and calcium replacement therapy in South Asian patients with type 2 diabetes mellitus produced a significant decrease in both HbA1c $(\mathrm{p}<0.001)$ and weight, which might be due to the increase in vitamin $\mathrm{D}_{3}$ levels post treatment. ${ }^{11}$ Krul et al also noted a significant $(\mathrm{p}=0.02)$ inverse relationship between $\mathrm{HbA} 1 \mathrm{c}$ and vitamin $\mathrm{D}_{3}$ level in a sub group of vitamin $\mathrm{D}_{3}$ deficient subjects. ${ }^{8}$

However, the study carried out by Ohk et al did not find any significant change in the $\mathrm{HbA1C}$, FBS with an increase in vitamin $\mathrm{D}_{3}$ levels. ${ }^{6}$ This supports the hypothesis that glycemic control depends on multiple factors and vitamin $\mathrm{D}_{3}$ level is not the only governing factor. The above studies support the findings of the present study that the vitamin $\mathrm{D}_{3}$ levels can have a role in glycemic control on type 2 diabetes mellitus patients.

Based on above results it can be assumed that it would be advisable to correct the vitamin $\mathrm{D}_{3}$ level in all patients suffering from type 2 diabetes. Accordingly, vitamin $\mathrm{D}_{3}$ has been administered to patients with diabetes mellitus type $2 .{ }^{12}$

In a study carried out Hamid et al in 2014 to assess the efficacy of supplementation of vitamin $\mathrm{D}$ on improvement on glycemic parameters in patients having type $2 \mathrm{DM}$ in a randomized double blind clinical trial, the authors noted that that significant improvement in glycemic control was observed only in the male subjects $(\mathrm{p}=0.0068) .{ }^{5}$ However in our study improvement in glycemic control was observed in both the genders.

The present study observed that in Gp2 also HbA1c, FBS and PP2BS significantly improved $(\mathrm{p}<0.05)$ though there was no supplementation of vitamin $\mathrm{D}_{3}$ in this group, however, the vitamin $\mathrm{D}_{3}$ levels were maintained and mean $(39.4 \mathrm{ng} / \mathrm{ml})$ was higher than in the Gp1 $(30.7$ 
ng/ml). Advice and counselling about the dietary modification and life style changes of patients might have been a probable factor for this improvement. ${ }^{13-15}$ This also suggests that glucose homeostasis in type 2 diabetes mellitus is affected by multiple factors.

The present study shows that in type 2 diabetic patients, vitamin $\mathrm{D}_{3}$ levels were found to be negatively correlated with glycosylated hemoglobin levels. The present study noted that in type 2 diabetes subjects having vitamin $\mathrm{D}_{3}$ deficiency (Gp1), there is a significant improvement in $\mathrm{HbA} 1 \mathrm{c}$ levels post vitamin $\mathrm{D}_{3}$ supplementation. There is also a significant improvement in glucose homeostasis in this group.

Based on above results, it would be physiologically correct to recommend vitamin $\mathrm{D}_{3}$ supplementation to improve glucose control in type 2 diabetes mellitus patients along with counseling for dietary modification and life style changes.

\section{Limitations}

Study assumed that the subjects kept their medication doses constant. Study also assumed that subjects had complied with the vitamin $\mathrm{D}_{3}$ doses prescribed during the study. Study may not represent the whole population. Study did not account for vitamin $\mathrm{D}_{3}$ variation with change in season during the period of the study.

\section{Implications of research}

In patients of type 2 diabetes with vitamin $\mathrm{D}_{3}$ deficiency, supplementation of vitamin $\mathrm{D}_{3}$ may be advised in order to enable better glycemic control and improvement in clinical outcome. This may also help in prevention of other complications associated with un-controlled blood sugar levels in patients with type 2 diabetes mellitus.

\section{CONCLUSION}

On the basis of our study, we observed that those having vitamin $\mathrm{D}_{3}$ deficiency are likely to have an early onset of diabetes mellitus and we found a positive association between vitamin $\mathrm{D}_{3}$ status and glycemic control in type 2 diabetic mellitus patients. Moreover, it was also noted that type $2 \mathrm{DM}$ is a multi-factorial disease and it is unlikely that vitamin $\mathrm{D}_{3}$ deficiency alone would be a major cause of disease or a major therapeutic target. However, vitamin $\mathrm{D}_{3}$ supplementation may have a role in glycemic control and it is recommended to correct the deficient patients by supplementing vitamin $D_{3}$ adequately.

Further randomized controlled trials for longer duration and large cross section of the population is recommended to better define the clinical role of vitamin $\mathrm{D}_{3}$ as potential intervention for prevention and management of type 2 diabetes.
Funding: No funding sources

Conflict of interest: None declared

Ethical approval: The study was approved by the Institutional Ethics Committee

\section{REFERENCES}

1. Liu E, Meigs JB, Pittas AG, Economos CD, Mckeown NM, Booth SL, et al. Predicted 25hydroxyvitamin D score and incident type 2 diabetes in the Framingham offspring study. Am J Clin Nutr. 2010;91:1627-33.

2. Eliades M, Pittas AG. Vitamin D and type 2 diabetes. Clinic Rev Bone Miner Metab. 2009;7:185.

3. Sabherwal S, Bravis V, Devendran D. Effect of oral vitamin $\mathrm{D}$ and calcium replacement on glycaemic control in South Asian patients with type 2 diabetes. Int J Clin Pract. 2010;64(8):1084-9.

4. American Diabetes Association. Standards of Medical Care in Diabetes 2016 Abridged for Primary Care Providers. Clin Diabetes. 2016;34(1):3-21.

5. Hamid N, Saeed B, Ahmad RM, Ali A, Parto N, Mahmoud R. Efficacy of supplementary vitamin D on improvement of glycemic parameters in patients with type 2 diabetes mellitus; a randomized doubleblind clinical trial. J Renal Inj Prev. 2014;3(1):31-4.

6. Ohk R, Sungwha L, Jaemyung Y, Moon C, Hyung J, Franco M. A prospective randomized controlled trial of the effects of vitamin D supplementation on longterm glycemic control in type 2 diabetes mellitus of Korea. Endocrine J. 2014;61(2):167-76.

7. Kumar H, Singh VB, Meena BL, Chandra S, Single R. Correlation of Vitamin D level with glycemic control in type 2 diabetes mellitus Sch. J App Med Sci. 2015;3:2277-83.

8. Krul YH, Wijland H, Stam F, Ten BE, Lips P, Simsek S. Studyprotocol: a randomised placebocontrolled clinical trial to study the effect of vitamin D supplementation on glycaemic control in type 2 Diabetes Mellitus Sunny trial. BMC Endocr Disord. 2014;14:59.

9. Pittas AG, Hughes DB. Vitamin D and diabetes. J Steroid Biochem Mol Biol. 2010;121:425-9.

10. Brijesh M, Saurav P. Prevalence of vitamin D deficiency in type-2 Diabetes Mellitus patients and its correlation with glycemic status. Int $\mathrm{J}$ Bioassays. 2014;3:3313-7.

11. Sabherwal S, Bravis V, Devendra D. Effect of oral vitamin $\mathrm{D}$ and calcium replacement on glycaemic control in South Asian patients with type 2 diabetes. Int J Clin Pract. 2010;64(8):1084-9.

12. Ifigenia KA, Panagiotis A, Anastasios G, Philippos K. Vitamin D and glycemic control in diabetes mellitus type 2. Ther Adv Endocrinol Metab. 2013;4(4):122-8.

13. Sanghani NB, Parchwani DN, Palandurkar KM, Shah AM, Dhanani JV. Impact of lifestyle modification on glycemic control in patients with type 2 diabetes mellitus. Indian J Endocrinol Metab. 2013;17(6):1030-9. 
14. Chen L, Pei JH, Kuang J, Chen HM, Chen Z, Li ZW, et al. Effect of lifestyle intervention in patients with type 2 diabetes: a meta-analysis. Metabolism. 2015;64(2):338-47.

15. Misa A, Kazue Y, Mariko W, Masako N, Eisuke H, Itsuro K, et al. Effects of lifestyle education program for type 2 diabetes patients in clinics: study design of a cluster randomized trial. BMC Public Health 2010;10:742.

Cite this article as: Banzal N, Desai A. The impact of vitamin D3 supplementation on glycemic control in type-2 diabetes mellitus at a tertiary care hospital. Int J Basic Clin Pharmacol 2020;9:1417-23. 